\title{
DETERMINATION OF LIDOCAINE IN WHOLE BLOOD BY GAS CHROMATOGRAPHY
}

\author{
G. Allakd Edhorv, pharm.m. ${ }^{*}$
}

THE STUDY of drug metabolism and blood level analysis of drugs have come into the limelight lately - and rightfully so! Not only does this broaden our general knowledge about drug action but it also focuses much needed light on the often biased issue of brand name drugs contra generic drugs.

When a blood level analysis is done for a local anaesthetic it is primarily to check that the blood level is at a minimum. This is the case when the anaesthetic is used locally for a nerve block or topical application. But if the anaesthetic is administered by a different route, as is the case with the recently introduced Xylocaine ${ }^{\circledR} \mathrm{HCl} 2$ per cent for Cardiac Arrhythmias, it is of course very important to maintain the blood level at an optimum.

The first step in a blood level analysis is to extract the drug from the complicated cell and plasma system with an organic solvent. The next step is to separate the solvent efficiently from the blood-water phase. Finally the solvent has to be prepared for further analysis.

One of the earliest methods for determination of a local anaesthetic in blood was developed by Sung and Truant for lidocaine. ${ }^{1}$ This was a colorimetric method using methyl orange.

During the last decade gas chromatography has developed rapidly as the method of choice for determination of biologically active substances in minute amounts even down to nanogram level. A solid foundation is thus laid for sensitive and accurate blood level analysis of drugs. In the local anaesthetic field more than a dozen gas chromatographic methods have been published. ${ }^{2-18}$ The multiplicity of the procedures is a good indicator for the difficulties involved.

Very few of the published methods have, however, stressed the major obstacles for a successful analysis, namely "impurities." These impurities turn up as peaks in the gas chromatogram, often interfering with lidocaine or internal standard peaks or they occur long after the important peaks, prolonging analysis time or spoiling the next run. Frustrated analysts blame nurses for contaminating samples. ${ }^{19}$ Other scapegoats have been drugs given prior to the major nerve block such as tranquilizers or narcotics. It is thus very important to establish the origin of those peaks and to find out how to evade them.

Modern gas chromatography is capable of a fantastic sensitivity. It is perfectly possible to determine lidocaine in blood with accuracy in an amount of less than $0.05 \mu \mathrm{g}$ (50 nanograms). The inaccuracy that may accompany the method lies more in the extraction method than in the gas chromatographic analysis, e.g.

\footnotetext{
"Control Laboratory, Astra Chemicals Ltd., Pharmaceutical Div., Middlegate Road, Mississauga, Ont.
} 
pipetting of an accurate amount of blood. With a sensitivity of such dimensions we are all of a sudden able to detect a variety of organic impurities which were entirely unknown before. We find that reagents and solvents previously considered pure now contain impurities which cannot be tolerated when they are used to detect drugs in nanogram amounts. We also find that glassware has to be exposed to more effective cleaning procedures to be rid of detergents or other organic debris. Purity and cleanliness take on a new dimension with gas chromatography as an analytical tool.

Determination of lidocaine in blood therefore demands:

Extremely clean glassware

Highly purified reagents and solvents

Heat resistant injection septa ${ }^{20.21}$

Efficient cleaning of the injection syringe

No contamination of reagents and solvents by contact with plastic or rubber. All these items should be tested for sufficient cleanliness one by one with gas chromatography prior to attempting to analyze blood.

\section{EQUIPMENT}

We have used a Varian 1740 Gas chromatograph - dual columns and hydrogen flame ionization detectors. Glass-columns, 18 in $\times 6$ feet, were packed with 4 per cent XF-1112 $2^{25}$ on Chromosorb w, AW, DMCs. Helium flow, $30 \mathrm{ml} / \mathrm{min}$. Hydrogen was supplied from a cylinder with gauges and an extra needle valve for fine adjustment for maximum efficiency. ${ }^{22}$ Filtered air from a tank was fed into the flames at about $300 \mathrm{ml} / \mathrm{min}$. Oven temperature was $205^{\circ} \mathrm{C}$ and injection ports and detectors were $240^{\circ} \mathrm{c}$. Columns were conditioned at $250^{\circ} \mathrm{c}$ for 12 hours with the detector ends of the columns disconnected. Microsyringe for sample injection was a $10 \mu \mathrm{l}$ Hamilton $710 \mathrm{I}_{\mathrm{N}}$ with a 2-in. needle and a Chaney adapter. Extraction tubes used were $12 \mathrm{ml}$ conical centrifuge tubes (Kimax 45196), $16 \mathrm{~mm}$. o.d. and $125 \mathrm{~mm}$ long with Teflon lined screw caps. For evaporation, open disposable tubes (Kimble 73000 ), $13 \mathrm{~mm}$ o.d. and $100 \mathrm{~mm}$. long, were used. Blood pipets were sterile, disposable, $1 \mathrm{ml}$ (Kimble 72 105), subdivided in $1 / 10 \mathrm{ml}$. For dispensing distilled water, sodium chloride 2.5 per cent and sodium carbonate $2 \mathrm{~N}$, a 2 -ml measuring pipet was useful. A microsyringe for accurately measuring of up to 0.35 $\mathrm{ml}(350 \mu \mathrm{l})$ is needed for lidocaine and internal standard solutions. Test tube shaker was a vibrator (Scientific Prod., Mod. s 8220). Centrifuge was a Mod. cL, Internat. Equipment, for 4 tubes. Evaporation of ether was done with a Temp-Blok Module (LabLine Instr.) with temperature set at about $70^{\circ} \mathrm{C}$. Freezing of samples was done in a deep freezer, capable of $-30^{\circ}$ c. Three specific gravity bottles (Hubbard-Carmick, $25 \mathrm{ml}$ ) were used for storage of (1) carbon disulfide for dissolving of samples for injection, (2) ethanol for cleaning, and (3) carbon disulfide for cleaning of the Hamilton syringe. Syringe needle can easily be inserted through the stopper hole and evaporation is thus diminished. The organic solvents can preferably be kept in a small plastic fume hood, supplied inside with a vacuum tube outlet with a Teflon tip. 


\section{REagents and Solvents}

Ether, reagent grade, redistilled prior to use in an all-glass apparatus. All contact with plastic or rubber must be avoided. Keep stock bottle in refrigerator. Carbon disulfide and carbon tetrachloride were spectroquality. Freshly distilled, sterile filtered water should be used for all reagents. If stored it must be kept in refrigerator to prevent bacterial growth and pvrogen formation - a commonly overlooked source of contamination.

Sodium carbonate $1 \mathrm{~N}$ is made from high quality powdered, anhydrous reagent. We have tested sodium hydroxide for alkalizing, but in our experience it was impossible to obtain free from impurities which interfered with lidocaine and the internal standard. The powdered sodium carbonate should be washed repeatedly with redistilled ether for purification and dried. Sodium chloride 2.5 per cent is made from sodium chloride powder which is likewise washed with redistilled ether and dried before making the solution. These solutions must be kept in glass stoppered bottles in the refrigerator to prevent bacterial growth.

\section{Lidocaine standard solution}

( $1 \mathrm{ml}=10 \mu \mathrm{g}$ lidocaine base )

Lidocaine (Xylocaine) HCl, monohydrate $\quad 0.0123 \mathrm{~g}$

Water, freshly distilled, filtered to $1000 \mathrm{ml}$

Keep about $200 \mathrm{ml}$ in a glass stoppered bottle in refrigerator for no longer than one week.

\section{Tripelennamine standard solution}

( $1 \mathrm{ml}=10 \mu \mathrm{g}$ tripelennamine base )

Tripelennamine $\mathrm{HCl}$ (Pyribenzamine) ${ }^{2 i}$

Water, freshly distilled, filtered to $1000 \mathrm{ml}$

$0.0114 \mathrm{~g}$

Keep about $200 \mathrm{ml}$ in a glass stoppered bottle in refrigerator for no longer than one week.

\section{Lidocaine, tripelennamine, test solution}

( $1 \mathrm{ml}=50 \mu \mathrm{g}$ base of each, $1 \mu \mathrm{l}=0.05 \mu \mathrm{g}$ base of each)

Lidocaine $\mathrm{HCl}$, monohydrate

Tripelennamine $\mathrm{HCl}$

Water, freshly distilled, filtered

$0.0616 \mathrm{~g}$

$0.0572 \mathrm{~g}$

to $1000 \mathrm{ml}$

Keep about $10 \mathrm{ml}$ of this solution in an extraction tube with Teflon-lined cap for testing of GC performance.

\section{Extraction for Calibration Curve}

A calibration curve is prepared for every patient. A blood sample $(8-10 \mathrm{ml})$ must therefore be taken from every patient before administration of the local 
TABLE I

Calibration Curve

\begin{tabular}{|c|c|c|c|c|c|}
\hline Reagent & $\begin{array}{l}\text { Blank } \\
\text { No. } 0\end{array}$ & No. 1 & No. 2 & No. 3 & No. 4 \\
\hline Water, freshly dist., filtere & $0.90 \mathrm{ml}$ & $0.60 \mathrm{ml}$ & $0.50 \mathrm{ml}$ & $0.40 \mathrm{ml}$ & $0.30 \mathrm{ml}$ \\
\hline Sodium & $0.50 \mathrm{ml}$ & $0.50 \mathrm{I}$ & $0.50 \mathrm{I}$ & 0,50 & $0.50 \mathrm{ml}$ \\
\hline Blood, local anaest & $1.0 \mathrm{ml}$ & & $1.0 \mathrm{~m}$ & $1.0 \mathrm{ml}$ & $1.0 \mathrm{ml}$ \\
\hline Tripelennamine stand. solution & & $0.25 \mathrm{ml}$ & $0.25 \mathrm{ml}$ & $0.25 \mathrm{ml}$ & $0.25 \mathrm{ml}$ \\
\hline Lidocaine stand. solution & & $0.05 \mathrm{ml}$ & $0.15 \mathrm{ml}$ & $0.25 \mathrm{ml}$ & $0.35 \mathrm{ml}$ \\
\hline Sodiu & $0.60 \mathrm{ml}$ & $0.60 \mathrm{ml}$ & $0.60 \mathrm{ml}$ & $0.60 \mathrm{ml}$ & \\
\hline Ether, redistill & $5.0 \mathrm{ml}$ & $5.0 \mathrm{ml}$ & $5.0 \mathrm{ml}$ & $5.0 \mathrm{ml}$ & 5.0 \\
\hline
\end{tabular}

TABLE II

UNKNOW'N SAMPLES

\begin{tabular}{llll}
\hline \multicolumn{1}{c}{ Reagent } & No. & No.6 & etc. \\
\hline Water, freshly distilled, filtered & $0.65 \mathrm{ml}$ & $0.65 \mathrm{ml}$ \\
Sodium chloride 2.5 per cent & $0.50 \mathrm{ml}$ & $0.50 \mathrm{ml}$ \\
Blood from sample No. 5, No. 6, etc. & $1.0 \mathrm{ml}$ & $1.0 \mathrm{ml}$ \\
Tripelennamine stand. solution & $0.25 \mathrm{ml}$ & $0.25 \mathrm{ml}$ \\
Sodium carbonate 1N & $0.60 \mathrm{ml}$ & $0.60 \mathrm{ml}$ \\
Ether, redistilled & $5.0 \mathrm{ml}$ & $5.0 \mathrm{ml}$ \\
\hline
\end{tabular}

anaesthetic. For lidocaine determination about $3-5 \mathrm{ml}$ blood is usually needed. Five extraction tubes are prepared and numbered for every patient for a calibration curve and further one tube for each unknown sample (Tables I and II). A corresponding number of evaporation tubes (disposable and sterile) are set up and numbered.

Using a disposable pipet, $1.0 \mathrm{ml}$ blood is pipetted into a sodium chloride mixture to form a normal saline solution. It is mixed with a vibrator for 10 seconds. Internal standard and lidocaine standard is added with a micropipet, followed by $10 \mathrm{sec}$ of mixing. Sodium carbonate $1 \mathrm{~N}$ is added and tubes vibrated for $10 \mathrm{sec}$. After addition of ether, tubes are carefully fitted with Teflon-lined caps and tested for leaking. Four test tubes are then gently shaken by turning, held by hand, from vertical to horizontal to vertical position about 1 turn per second for $1 / 2$ minute. More violent shaking will result in a variety of unwanted peaks from blood components. Caps are then removed and the four tubes immediately centrifuged (speed 5) for about $10 \mathrm{~min}$. Tubes are placed in a deep freezer at $-30^{\circ} \mathrm{c}$.

When bottom layer (blood) has solidified after about 15 minutes, tubes are gently tapped for sedimentation of crystals and when settled, the top layer (ether) is carefully decanted into an evaporation tube with the same number. Ether is then evaporated in the heater in a fume hood at about $70^{\circ} \mathrm{C}$ until complete dryness.

\section{Extraction for UnKNown Samples}

This extraction is done exactly as previously. Note, however, that lidocaine standard solution is not added here (Table II). 


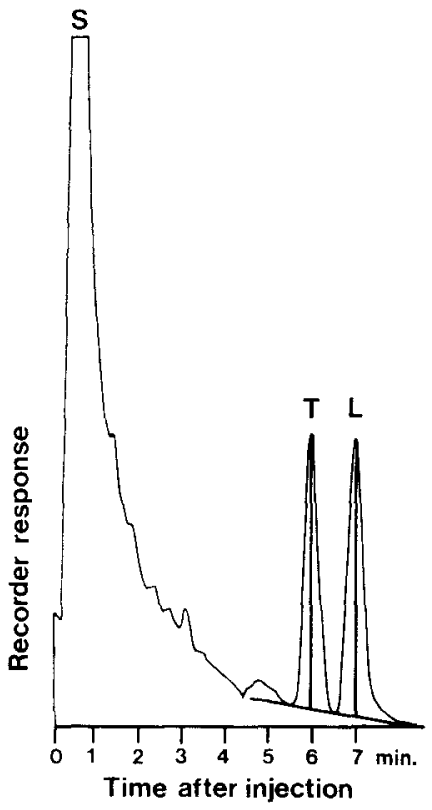

Figure 1. Gas chromatogram of lidocaine from whole blood, tripelennamine as internal standard, sample No. 3, calibration curve.

s-solvent peak. $\mathrm{T}$ - tripelennamine, retention time 6 min, peak height $56 \mathrm{~mm}$. L - lidocaine, retention time $7 \mathrm{~min}$, peak height $55 \mathrm{~mm}$.

Ratio: lidocaine/tripelennamine $=55 / 56=0.98$. Glass columns, $3.2 \mathrm{~mm}$ i. d. $\times 3 \mathrm{~m}$ (1 18 in. i. d. $\times 6$ feet), packed with 4 per cent XF - 1112 on Chromosorb w, Aw, DMcs. Oven temp. $205^{\circ}$ $\mathrm{C}$, injector and detector temp. $240^{\circ} \mathrm{C}$. Recorder speed, 落 in. per min. Attenuation, $4 \times 10^{-11}$ Ether extract of $1 \mathrm{ml}$ blood, dissolved in $25 \mu \mathrm{l} \mathrm{CS}$ (with 4 per cent $\left.\mathrm{CCl}_{4}\right), 2 \mu \mathrm{l}$ injected on column.

\section{Gas Chromatographic Determination}

Content of local anaesthetic and internal standard in the evaporated test tube is dissolved in about $25 \mu \mathrm{l}$ carbon disulfide by using the vibrator. We have found the addition of 4-5 per cent carbon tetrachloride to carbon disulfide to be advantageous to prevent negative peaks and for a more stable baseline. Complete filling of the needle of the microsyringe is facilitated by sucking up solution repeatedly and disposing it again in the tube, thereby washing the sides of the tube. Finally, measure $2 \mu \mathrm{l}$ in the now completely filled syringe and inject on 
TABLE III

Retention Time and Mol. W. for Some Local Anaesthetics and Internal Standards

\begin{tabular}{lcccc}
\hline \multicolumn{1}{c}{ Agent } & $\begin{array}{c}\text { Relative } \\
\text { retention time } \\
\text { lidocaine }=1.00\end{array}$ & $\begin{array}{c}\text { Mol.w. } \\
\text { HCl salt }\end{array}$ & $\begin{array}{c}\text { Mol.w. } \\
\text { base }\end{array}$ & $\begin{array}{c}\text { factor } \\
\text { HCl salt/base }\end{array}$ \\
\hline Tripelennamine (Pyribenzamine ${ }^{\circledR}$ ) & 0.84 & 291.8 & 255.4 & 1.143 \\
Prilocaine (Citanest ${ }^{\circledR}$ ) & 0.87 & 256.8 & 220.3 & 1.165 \\
Cyclizine (Marzine ${ }^{\circledR}$ ) & 0.89 & 302.8 & 266.4 & 1.137 \\
Lidocaine (Xylocaine & 1.00 & 288.8 & 234.3 & 1.232 \\
Procaine (Novocain ${ }^{\circledR}$ ) & 1.83 & 272.8 & 236.3 & 1.154 \\
Mepivacaine (Carbocaine ${ }^{\mathbb{B}}$ ) & $\mathbf{1 . 8 5}$ & $\mathbf{2 8 2 . 8}$ & 246.3 & $\mathbf{1 . 1 4 8}$ \\
\hline
\end{tabular}

FIG 2. CALIBRATION GRAPH FOR LIDOCAINE IN BLOOD

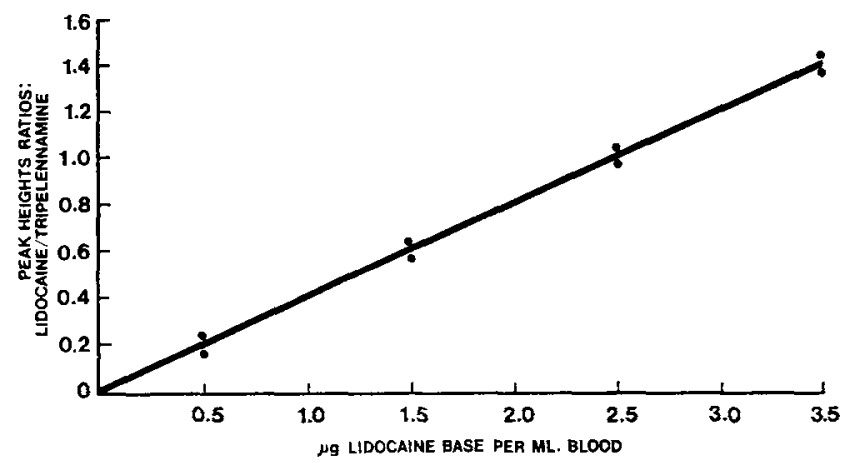

column into GC, after adjusting of attenuation and baseline and simultaneously starting the clock. Tripelennamine usually emerges at about 6 minutes and lidocaine after 7 minutes. With oven temperature of $205^{\circ} \mathrm{c}$, one analysis thus takes 8-10 minutes (Figure 1).

It is a common experience that after a couple of hours work, interfering peaks occur. These may be caused by poor quality injection septa or by cholesterol or other impurities extracted by ether from blood plasma. Analysis can be stopped and temperature in the oven raised to $250^{\circ} \mathrm{C}$ for one half hour to drive out impurities. Burner nozzles and detectors should be cleaned often (once or twice a week) and organic debris or rust must be removed from detector walls and probes. Injection of 10-50 $\mu \mathrm{l}$ Silyl-8 column conditioner ${ }^{30}$ may temporarily restore column efficiency. It is advantageous to keep gas chromatograph running constantly even overnight with only the recorder switched off. The loss of gases will be compensated for by the time saved.

\section{INTERNAL STANDARDS}

Tripelennamine ${ }^{27}$ (Pyribenzamine ${ }^{\circledR}$ ) has in our series given the best results because of ideal retention time in respect to lidocaine. With very efficient columns Prilocaine (Citanest ${ }^{29}$ or Cyclizine (Marzine $\left.{ }^{\circledR}\right)^{28}$ can be used. These peaks will come out closer to lidocaine. 


\section{Calibration Curve:}

Sample No. 0 will give information about impurities in the reagents and or impurities extracted from blood. Samples No. 1 to No. 4 are used for construction of a calibration curve covering the range of lidocaine $0-3.5 \mu \mathrm{g}$ base per $\mathrm{ml}$ blood (Figure 2). As most results will fall in the range $0-2.5 \mu \mathrm{g}$ per $\mathrm{ml}$, only three points on the curve may be needed and No. 4 (as well as No. 0) can in most cases be skipped. Measure peak heights of lidocaine and tripclennamine in $\mathrm{mm}$ for each run and find the ratio. These ratios often come very close to the theoretical values: No. $1-0.2$; No. 2-0.6; No. 3-1.0; No. 4-1.4. Plot the obtained ratios on $y$-axis and the true content of lidocaine in $\mu \mathrm{g} / \mathrm{ml}$ on $\mathrm{x}$-axis: No. $1-0.5 \mu \mathrm{g} / \mathrm{ml}$; No. $2-1.5$ $\mu \mathrm{g} / \mathrm{ml}$; No. $3-2.5 \mu \mathrm{g} / \mathrm{ml}$; and No. 4-3.5 $\mu \mathrm{g} / \mathrm{ml}$.

\section{Cheanivg of Extraction Tubes}

As test tubes with caps have to be used for extraction to make it possible to shake the samples gently, the extraction tubes are used over again after careful cleaning. We have found the following procedure sufficient:

1. detergent, brush and tap water

2. ultrasonic cleaning with detergent (Alcanox)

3. rinsing with distilled water and drying in hot oven

4. rinsing with ethyl alcohol with vibrator

5. rinsing twice with redistilled ether with vibrator

6. drying in air

\section{Cleaning of the Hamilton Syminge}

It is of paramount importance to have the Hamilton syringe cleaned immediately after use. If allowed to dry, organic debris will accumulate, resulting in clogging and bending of plunger. Small remaining amounts of solution in the dead space of the needle may render all accurate analysis impossible. Dry needle with tissue paper and disassemble syringe, wiping off the plunger without bending it. Flush ethyl alcohol through syringe by dipping needle into washbottle and applying vacuum with a Teflon tipped line from behind. Vacuum dry. Immerse needle into $\mathrm{CS}_{2}$ washbottle and flush finally dry. Insert plunger, flush with $\mathrm{CS}_{2}$ repeatedly and dispose into drain bottle. Disassemble and vacuum dry.

\section{Testing: of Solvent, Reagents, and Tubes}

A natural sequence of testing is the following:

Carbon disulfide, injection septa and the Hamilton syringe

Inject $2 \mu \mathrm{l}$ carbon disulfide on column.

Ether, redistilled, evaporation tubes or extraction tubes

Evaporate $5 \mathrm{ml}$ redistilled ether in an evaporation or extraction tube to dryness. Dissolve remainder in $25 \mu \mathrm{l} \mathrm{CS}$. and inject $2 \mu \mathrm{l}$. 


\section{Distilled, filtered water}

Shake about $10 \mathrm{ml}$ distilled water in a separatory funnel (etherwashed!) with a Teflon stopcock with $5 \mathrm{ml}$ redistilled ether. Discard water and evaporate ether to dryness in an evaporation tube. Dissolve in $25 \mu \mathrm{CS}_{2}$ and inject $2 \mu \mathrm{l}$ on column.

Sodium carbonate $1 \mathrm{~N}$ and Sodium chloride 2.5 per cent

Extract $10 \mathrm{ml}$ reagent as in above.

\section{SUMMARY}

Lidocaine (Xylocaine) has recently been introduced on the Canadian market for intravenous use in arrhythmias. This has created a demand for a rapid and reliable method to determine lidocaine in whole blood for estimation of optimum intravenous drip speed.

Several methods to determine blood level of local anaesthetics have been published but none of them deals with the main difficulties involved, namely impurities from improperly cleaned glassware or insufficiently pure reagents or solvents. This article emphasizes the extremely high sensitivity of gas chromatography for biological analysis and testing of all utilized glassware, reagents, and solvents is recommended. Extraction procedure is simple and rapid. Methods for prevention and elimination of impurity peaks are given. Extremely careful cleaning procedures for tubes, pipets, and syringes are suggested or alternatively the use of sterile, disposable evaporation tubes and pipets is recommended.

Blood, $1.0 \mathrm{ml}$, diluted with a sodium chloride mixture to form a normal saline, is extracted with $5 \mathrm{ml}$ redistilled ether after alkalizing with $0.6 \mathrm{ml}$ sodium carbonate $1 \mathrm{~N}$. Tripelennamine (Pyribenzamine ${ }^{\circledR}$ ), Cyclizine (Marzine ${ }^{\circledR}$ ), or Prilocaine (Citanest ${ }^{(B)}$ are recommended as internal markers. Extraction is done in 12-ml centrifuge tubes covered with Teflon-lined caps by gently turning tubes by hand, 4 tubes at a time. Tubes are centrifuged for 10 minutes and quickly frozen at $-30^{\circ} \mathrm{c}$. Ether layer is decanted into a clean disposable evaporation tube and ether evaporated to dryness. The residue is dissolved in $25 \mu \mathrm{l} \mathrm{CS_{2 }}$ and about 2 $\mu l$ injected on column of a gas chromatograph with hydrogen flame detector.

With the practical directions in this article, an analyst with only limited experience in gas chromatography should be able to obtain good results even from the beginning of a test series for lidocaine in whole blood without being disturbed by impurity peaks from reagents and solvents.

\section{RÉSUMÉ}

Récemment, sur le marché Canadien, est apparue la lidocaïne qui s'administre par voie endoveineuse dans le traitement de l'arythmie. Ce fait a créé la demande d'une méthode rapide et fiable pour déterminer le taux de lidocaine dans le sang et préciser ainsi la vitesse optimale d'un goutte à goutte intra-veineux.

Plusieurs méthodes pour déterminer la concentration des anesthésiques locaux dans le sang ont été publiées, mais aucune d'elles ne parle des principales difficultés rencontrées à savoir les impuretés causées par des contenants mal nettoyés ou des 
réactifs ou solvants impurs. Notre article insiste sur la très grande sensibilité de la chromatographie des gaz pour l'analyse biologique et l'évaluation de tous les contenants en verre, les réactifs et les solvants. La technique d'extraction est simple et rapide. Les méthodes pour la prévention et élimination des sommets d'impureté sont données. Nous suggérons une technique des plus soigneuses pour le nettoyage des tubes, des pipettes et des seringues ou nous recommandons également l'usage de pipettes et de tubes d'évaporation stérile et uniservice.

Un $\mathrm{ml}$ de sang, dilué avec une solution de chlorure de sodium pour former une solution saline normale, est extrait avec $5 \mathrm{ml}$ d'éther redistillée après une alcalinisation avec $0.6 \mathrm{ml}$ de carbonate de sodium $\mathrm{IN}_{\mathrm{N}}$. Nous recommandons la Tripelennamine (Pyribenzamine $\left.{ }^{(}\right)$, la Cyclizine (Marzine $\left.{ }^{(}\right)$, ou la Prilocaïne (Cinatest ${ }^{\circledR}$ ) comme marqueurs internes. L'extraction est faite dans des tubes centrifuges de $12 \mathrm{ml}$ couverts de bouchons de Teflon rayé en tournant délicatement les tubes à la main, quatre tubes à la fois. Les tubes sont centrifugés durant 10 minutes et refroidis rapidement à $-30^{\circ} \mathrm{c}$. On décante la couche d'éther dans un tube d'évaporation uniservice stérile et propre et l'éther est évaporé jusquà sécheresse. Le résidu est dissout dans $25 \mu \mathrm{l}$ de $\mathrm{CS}_{2}$ et environ $2 \mu \mathrm{l}$ sont injectés sur la colonne du chromatographe à gaz avec un détecteur à flamme hydrogène.

A l'aide des directives pratiques données dans cet article, un analyste possédant une expérience limitée dans la chromatographie au gaz devrait pouvoir obtenir cle bons résultats dès le début d'une série de tests pour la lidocaïne dans le sang total sans ètre dérangé par des sommets d'impuretés venant des réactifs et des solvants.

\section{ACKNOWLEDGMENTS}

I gratefully acknowledge valuable technical advice from Joseph B. Keenaghan, Research Chemist in Analytical Chemistry, Laboratory of Biological Research, Astra Pharmaceutical Products, Inc., Worcester, Mass, and from Mrs. Görel Österlöf, the Control Laboratories of AB Astra, Södertälje, Sweden. Mr. Dino La Caprara, Research Assistant, has spared no effort to keep the gas chromatograph geared to the highest sensitivity during this test series. Dr. A. Wassef, Ciba Company Ltd., Dorval, P.Q., has becn kind enough to supply the Pyribenzamine.

\section{REFERENCES}

1. Strg, F. \& Truaxt, A. P. The physiological disposition of lidocaine and its comparison in some respects with procaine. J. Pharmacol. Exp. Ther. 112: 432 ( 1954 ).

2. Byars, B. Aerograph Research Notes, Fall Issue (1964).

3. Koenler, H. M. \& Hefrerrex, J. J. Gas liquid chromatography of local anaesthetics and related compound. J. Pharm. Sciences. 53: 7, 745 (1964).

4. Becket, A. H.: Boyes, R. N.: \& PARKer, J. B. R. Determination of lignocaine in hlool and urine in human subjects undergoing local analgesic procedures. Anaesthesia. 20: 294 (1965).

5. Srinhufrtd, G.: Ortengrex, B.; \& Jacobsson, S.-E. The estimation of lidocaine and prilocaine in biological material by gas chromatography. Scand. J. Clin. \& Lab. Inv. 17: 162 (1965)

6. Dhunér, K. G.: Hahthon, J. G. L.; Herbring, B. G.; \& Lie, T. Blood levels of mepivacaine after regional anaesthesia. Brit. J. Anaesthesia. 37: 746 (1965).

7. Kristersox, L.; Hofrman, P.; \& Hansson, E. Fate of mepivacaine in the body. Acta Pharmacologica. 22: 205 (1965).

8. KAтz, J. Stability of local anaesthetics after autoclaving: determined by gas chromatography. Anesthesiology. Nov-Dec, 835 (1966). 
9. Pratt, E. L.; Warrivgtox, H. P.; \& Grego, J. The gas chromatographic determination of mepivacaine in blood with a note on other local anaesthetics. Anesthesiology. 28: 432 (1967).

10. Daniel, S. S. \& Mormshrma, H. W. Estimation of mepivacaine $\mathrm{HCl}$ in biological fluids. Anesthesiology. 28: 924 (1967).

11. Keenaghan, J. B. The determination of lidocaine and prilocaine in whole blood by gas chromatography, Anesthesiologv. Jan.-Feb.: 110 (1968).

12. Shnimer, S. M. \& Way, S. L. Plasma levels of lidocaine (Xylocaine) in mother and newborn following obstetrical conduction anaesthesia: clinical applications. Anesthesiology. 29: 951 (1968).

13. ReYnolds, F. \& BeCKetT, A. H. The determination of bupivacaine, lignocaine and mepivacaine in human blood. J. Pharm. Pharmacol. 20:704 (1968).

14. Yoshikawa, K., Mma, T. et al. Blood level of Marcaine in axillary plexus blocks, intercostal nerve blocks and epidural anaesthesia. Acta anaesth. Scand. 12, Jan. 1 (1968).

15. Asling, J. H.; Shnmere, S. M.; Wilkinson, G. R.; \& WAY, E. L. Gas chromatographic determination of mepivacaine in capillary blood. Anesthesiology. 31: 458 (1969).

16. Maes, R.; Kananen, G.; \& Sunshive, I. Determination of Mepivacaine in blood and urine. Anesthesiology. 657 (1969).

17. Thorn-Alquist, A. M. Blood concentrations of local anaesthetics after intravenous regional anaesthesia. Acta Anaesth. Scand. 13: 229 (1969).

18. Moore, D. C.; Bridenbaugh, L. D.; Bridenbaugh, P. O.; \& Tucker, G. T. Bupivacaine Hydrochloride: Laboratory and Clinical studies. Anesthesiology. 78 (1970).

19. HAAHTI, E. Major lipid constituents of human skin surface with special reference to gaschromatographic methods. Scand. J. Clin. Lab. Invest., 13, Suppl. 59 (1961).

20. Tamsma, A.; Kurtz, N. R.; \& Pallansch, M. J. Preconditioning of septums to reduce eluate contamination and anomalous peaks during temperature programming. J. Gas Chromatography. 271 (1967).

21. Tucknotr, O. G. \& Williams, A. A. Injection port modification to prevent septa bleeding in programmed temperature gas-liquid chromatography. Anal. Chem. 41, 14: 2086 (1969).

22. Gas-Chrom Newsletter, Vol. II, 2: 4. How to get maximum fid response. Applied Science Laboratories, Inc., State College, PA 16801.

23. Holnunger, G. On the metabolism of lidocaine I and ir. Acta Pharmacol. et Toxicol. 17: $356(1960)$.

24. Heinones, J. Influence of some drugs on toxicity and rate of metabolism of lidocaine and mepivacaine. Annales Med. Exper. Biol. Fenn. Vol. 44, Suppl. 3 (1966).

\section{SUPPLIERS}

25. Liquid phase XF-1112 is obtainable from Hewlett-Packard, Avondale Div., Avondale, Penna 19311, U.S.A.

26. Lidocaine $\mathrm{HCl}$ monohydrate (Xylocaine ${ }^{\circledR} \mathrm{HCl}$ monohydrate) is obtainable for analytical purposes from Astra Chemicals Ltd., Pharmaceutical Div., 1004 Middlegate Road, Mississauga, Ont.

27. Tripelennamine (Pyribenzamine ${ }^{\circledR}$ ) $\mathbf{H C l}$ is obtained from Ciba Company Ltd., Pharmaceutical Div., Dorval, P.Q.

28. Cyclizine (Marzine $\left.{ }^{\circledR}\right) \mathrm{HCl}$ obtained from Pfaltz \& Bauer, Inc., 126-04 Northern Blvd., Flushing, N.Y. 11368, U.S.A.

29. Prilocaine (Citanest $\left.{ }^{(}\right) \mathrm{HCl}$ obtainable for analytical purposes from Astra Chemicals Ltd., 1004 Middlegate Road, Mississauga, Ont.

30. Silyl-8 column conditioner can be obtained from Pierce Chemical Co., P.O. Box 117, Rockford, Ill. 61105, U.S.A. 